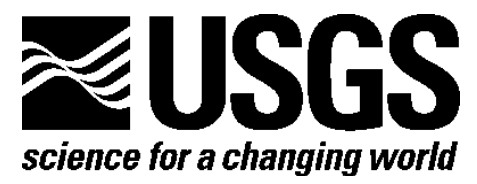

Prepared in cooperation with the Colorado Department of Transportation

\title{
Web-Based Flood Database for Colorado, Water Years 1867 through 2011
}

By Michael S. Kohn, Robert D. Jarrett, Gary S. Krammes, and Amanullah Mommandi

Open-File Report 2012-1225

U.S. Department of the Interior

U.S. Geological Survey 


\section{U.S. Department of the Interior \\ KEN SALAZAR, Secretary}

\section{U.S. Geological Survey \\ Suzette M. Kimball, Acting Director}

U.S. Geological Survey, Reston, Virginia: 2013

For more information on the USGS-the Federal source for science about the Earth,

its natural and living resources, natural hazards, and the environment-visit

http://www.usgs.gov or call 1-888-ASK-USGS

For an overview of USGS information products, including maps, imagery, and publications, visit $h$ ttp://www.usgs.gov/pubprod

To order this and other USGS information products, visit http://store.usgs.gov

Suggested citation:

Kohn, M.S., Jarrett, R.D., Krammes, G.S., and Mommandi, Amanullah, 2013, Web-based flood database for Colorado, water years 1867 through 2011: U.S. Geological Survey Open-File Report 2012-1225, 26 p.

Any use of trade, product, or firm names is for descriptive purposes only and does not imply endorsement by the U.S. Government.

Although this report is in the public domain, permission must be secured from the individual copyright owners to reproduce any copyrighted material contained within this report. 


\section{Acknowledgments}

Kenneth Odom, formerly of the U.S. Geological Survey (USGS), provided valuable advice and direction for the creation of the flood database. John England of the Bureau of Reclamation previously compiled flood data that were eventually used in the flood database. Steve Anders, Rick Crowfoot, Ben Glass, John Kuzmiak, and Greg Smith, all of the USGS, were extremely helpful in compiling flood data. Andy Bock, USGS, operated the Environmental Systems Research Institute ArcGIS 10 tools, which generated data that were incorporated into the flood database. John Fulton and Jon Nania of the USGS provided beneficial suggestions for this report as peer reviewers. 


\section{Contents}

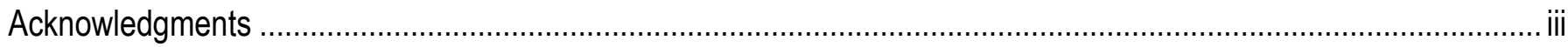

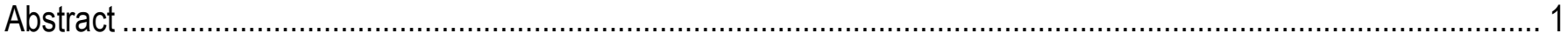

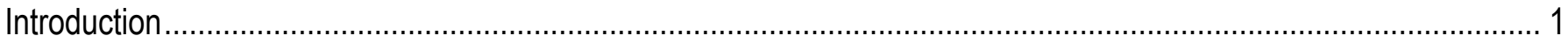

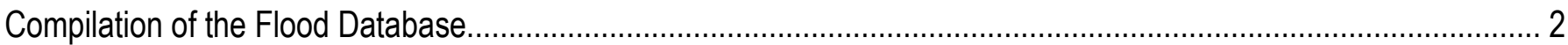

Data Sources and Descriptions of Data ............................................................................................... 3

Indirect Discharge Measurements Stored in U.S. Geological Survey Offices................................................... 5

Indirect Discharge Measurements in U.S. Geological Survey Reports............................................................ 8

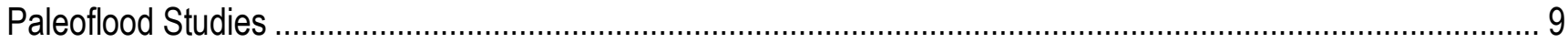

U.S. Geological Survey National Water Information System Peak-Discharge Database ....................................12

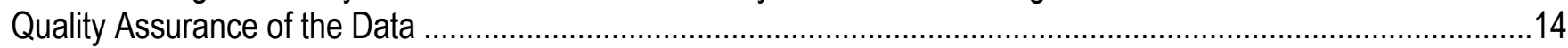

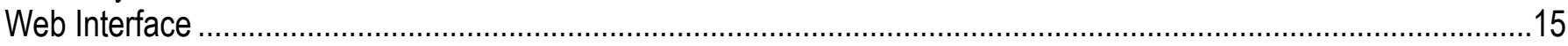

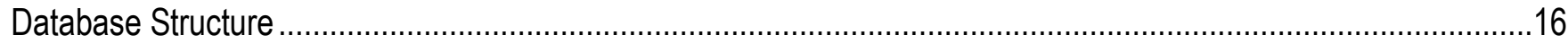

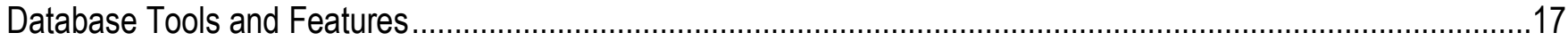

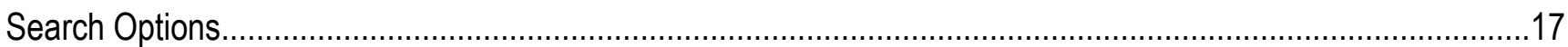

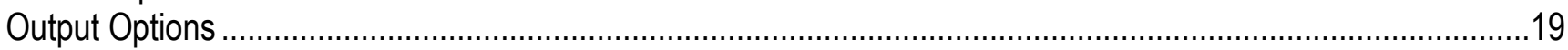

Summary

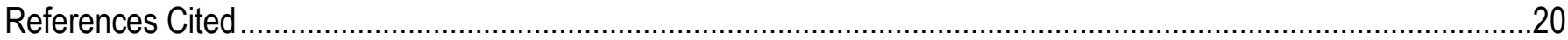

Appendix 1 


\section{Figures}

Figure 1. Location of 549 sites with indirect discharge measurements stored in U.S. Geological Survey offices in Colorado, water years 1867 through 2011.

Figure 2. Location of the 175 flood sites in Colorado with indirect discharge measurements in U.S. Geological Survey reports, water years 1884 through 2011

Figure 3. Location of the 29 paleoflood study sites in Colorado published in six peer-reviewed journal articles (England and others, 2003; England and others, 2010; Grimm and others, 1995; Jarrett, 2000; Jarrett and Tomlinson, 2000; Pruess and others, 1998).

Figure 4. Location of the 1,184 sites in the Colorado flood database obtained from the U.S. Geological Survey National Water Information System peak-discharge database, water years 1883 through 2010........................... 14

Figure 5. Screen capture of the home page of the flood database with all 1,597 flood sites in Colorado............... 16

Figure 6. Screen capture of the search and filter toolbars of the Colorado flood database .................................. 18

Figure 7. Screen capture of the data export tab in the Colorado flood database .............................................. 19

Figure 1-1. Screen capture of the search and filter options for the example search for floods in Jefferson County in the Colorado flood database.

Figure 1-2. Screen capture of the site information tab with results for the example search in the Colorado flood database.

Figure 1-3. Screen capture of the indirect measurements tab with results for the example search in the Colorado flood database.

Figure 1-4. Screen capture of the paleoflood events tab with results for the example search in the Colorado flood database....

Figure 1-5. Screen capture of the peak-discharge events tab with results for the example search in the Colorado flood database.

Figure 1-6. Screen capture of the data export tab with results in an ASCII file for all the data fields for each event in the example search in the Colorado flood database

\section{Tables}

Table 1. Data fields composing the Colorado flood database for each flood site. 4

Table 2. Data fields composing the Colorado flood database for each flood event, based on data source ...............5

Table 3. The 14 field methods used to compute U.S. Geological Survey indirect discharge measurements for streams in Colorado

Table 4. Peer-reviewed journal articles related to floods in Colorado with the authors, journals, and dates of the paleoflood studies that were included in the Colorado flood database 


\section{Conversion Factors}

Inch/Pound to SI

\begin{tabular}{lcl}
\hline \multicolumn{1}{c}{ Multiply } & \multicolumn{1}{c}{ By } & \multicolumn{1}{c}{ To obtain } \\
\hline inch (in.) & Length & \\
inch (in.) & 2.54 & centimeter $(\mathrm{cm})$ \\
foot (ft) & 25.4 & millimeter $(\mathrm{mm})$ \\
mile (mi) & 0.3048 & meter $(\mathrm{m})$ \\
\hline & 1.609 & kilometer $(\mathrm{km})$ \\
\hline square mile $\left(\mathrm{mi}^{2}\right)$ & Area & \\
square mile $\left(\mathrm{mi}^{2}\right)$ & 259.0 & hectare $($ ha) \\
\hline & 2.590 & square kilometer $\left(\mathrm{km}^{2}\right)$ \\
\hline cubic foot $\left(\mathrm{ft}^{3}\right)$ & Volume & \\
cubic foot $\left(\mathrm{ft}^{3}\right)$ & 28.32 & cubic decimeter $\left(\mathrm{dm}^{3}\right)$ \\
& 0.02832 & cubic meter $\left(\mathrm{m}^{3}\right)$ \\
\hline cubic foot per second $\left(\mathrm{ft}^{3} / \mathrm{s}\right)$ & Flow rate & \\
\hline
\end{tabular}

Vertical coordinate information is referenced to the North American Vertical Datum of 1988 (NAVD 88).

Horizontal coordinate information is referenced to the North American Datum of 1983 (NAD 83).

Elevation, as used in this report, refers to the distance above the vertical datum.

Water year in this report is defined as the period from October 1 st of one year through September 30th of the following year and is named for the year of the ending date. 


\title{
Web-Based Flood Database for Colorado, Water Years 1867 through 2011
}

By Michael S. Kohn, ${ }^{1}$ Robert D. Jarrett, ${ }^{1}$ Gary S. Krammes, ${ }^{1}$ and Amanullah Mommandi ${ }^{2}$

\begin{abstract}
In order to provide a centralized repository of flood information for the State of Colorado, the U.S. Geological Survey, in cooperation with the Colorado Department of Transportation, created a Web-based geodatabase for flood information from water years 1867 through 2011 and data for paleofloods occurring in the past 5,000 to 10,000 years. The geodatabase was created using the Environmental Systems Research Institute ArcGIS JavaScript Application Programing Interface 3.2. The database can be accessed at http://cwscpublic2.cr.usgs.gov/projects/coflood/COFloodMap.html.

Data on 6,767 flood events at 1,597 individual sites throughout Colorado were compiled to generate the flood database. The data sources of flood information are indirect discharge measurements that were stored in U.S. Geological Survey offices (water years 1867-2011), flood data from indirect discharge measurements referenced in U.S. Geological Survey reports (water years 1884-2011), paleoflood studies from six peer-reviewed journal articles (data on events occurring in the past 5,000 to 10,000 years), and the U.S. Geological Survey National Water Information System peak-discharge database (water years 1883-2010). A number of tests were performed on the flood database to ensure the quality of the data. The Web interface was programmed using the Environmental Systems Research Institute ArcGIS JavaScript Application Programing Interface 3.2, which allows for display, query, georeference, and export of the data in the flood database. The data fields in the flood database used to search and filter the database include hydrologic unit code, U.S. Geological Survey station number, site name, county, drainage area, elevation, data source, date of flood, peak discharge, and field method used to determine discharge. Additional data fields can be viewed and exported, but the data fields described above are the only ones that can be used for queries.
\end{abstract}

\section{Introduction}

The accuracy of flood-frequency estimates can be greatly improved when historical flood information is included with systematically collected flood data (Interagency Committee on Water Data, 1982). Although many reports contain flood information for streams in Colorado, there is no centralized repository for this information, making it difficult to access flood data. Prior to the completion of the Web-based flood database, much of the historical flood information for Colorado was stored in numerous published and unpublished reports and files in local, State, and Federal government agencies and the offices of engineering firms and

\footnotetext{
${ }^{1}$ U.S. Geological Survey, Denver, Colo.

${ }^{2}$ State of Colorado Department of Transportation, Denver, Colo.
} 
universities. Although considerable research has been conducted using historical flood information in flood-frequency analyses, this information is often underutilized because of the uniqueness of each site and a lack of knowledge of the site location. Having an easy-to-use, Web-based geodatabase of historical flood and paleoflood information with links to sources of flood data would allow engineers and water-resource managers to fully use these data to provide information on the largest floods and would lead to improved flood-frequency estimates of the largest floods in Colorado. The U.S. Geological Survey (USGS), in cooperation with the Colorado Department of Transportation, created a Web-based geodatabase for information on floods from water years 1867 through 2011 and information on paleofloods occurring in the past 5,000 to 10,000 years. (Water year in this report is defined as the period from October 1 st of one year through September 30th of the following year and is named for the year of the ending date.) The geodatabase was created using Environmental Systems Research Institute (ESRI) ArcGIS JavaScript Application Programing Interface (JavaScript API) 3.2. Engineers, scientists, and water-resource managers will be able to use these data for floodplain regulation, dam-safety, infrastructure design, and other uses.

The purpose of this report is to describe the Web-based geodatabase of flood information, the compilation of that information, and the use of the database. The data sources of flood information are indirect discharge measurements stored in USGS offices, indirect discharge measurements of floods referenced in USGS reports, paleoflood studies from six peer-reviewed journal articles, and the USGS National Water Information System (NWIS) peak-streamflow database, referred to as the "NWIS peak-discharge database" in this report. This report outlines the methods used to compile the data in the Web-based flood database and the features of the Web interface.

\section{Compilation of the Flood Database}

The four data sources discussed previously provided all the data for the Web-based flood database for Colorado, hereafter referred to as the "flood database." First, indirect discharge measurements, most of which were made by the USGS and are stored in paper files located in USGS offices throughout the State of Colorado, were compiled. Second, flood data for Colorado were gathered by searching all known relevant USGS publications. Third, a number of paleoflood studies conducted at USGS streamgages in Colorado and referenced in peer-reviewed journal articles (listed later in the report) were added to the flood database. Fourth, peakdischarge data for every site in Colorado stored in the USGS NWIS database (U.S. Geological Survey, 2011a) were compiled and included in the flood database. Both systematic and historical floods were included in the database. Systematic floods are floods that occurred at a streamgage during the period of record, whereas a historical flood occurred either at a streamgage outside the period of record or at a site with no streamgage.

Several flood events were recorded in more than one of the four data sources. In this case, an entry for each data source was included in the database. Discharges in the different data sources were determined using different techniques; it follows that different methods could have produced different discharge values.

Several flood events could occur at a single site, but many sites had just a single flood event. In some cases, multiple flood events were recorded in various data sources, but all the flood events shared a common site. Several flood events could have occurred in a single day as long as the sites were discrete. Information about the characteristics of the flood and physical characteristics of the site where the flood occurred was entered into the database. A total of 
6,767 flood events at 1,597 individual sites throughout Colorado were compiled to generate the flood database.

The sites of the flood events were limited to the State of Colorado with a few exceptions. Several streamgage sites are located beyond the State line but have data stored in USGS offices in Colorado. A few sites referenced in the USGS NWIS peak-discharge database for Colorado are located outside Colorado in neighboring states; these sites were included in the flood database. The Colorado Department of Transportation provided an ESRI ArcGIS coverage that geospatially references the milepost system in Colorado, so the flood database is spatially referenced to Colorado's milepost system.

\section{Data Sources and Descriptions of Data}

All relevant USGS data that could be compiled and included in the flood database efficiently were retrieved for each flood event. Only data originating with the USGS were included in the flood database. It was beyond the scope of this study to incorporate flood data from other sources, such as other Federal agencies, universities, consultants, State agencies, and local agencies, although the Colorado Division of Water Resources operates about the same number of streamgages in Colorado as the USGS. At a minimum, the approximate date and location (latitude and longitude) were needed for a flood to be included in the flood database. From the location, additional data fields could be populated for inclusion in the database, as discussed later in this section. Additionally, other data fields were determined and included in the flood database, depending on the data source. Table 1 lists the data fields created in the flood database for each flood site, and table 2 lists the data fields for each flood event based on the data source (indirect measurement data stored in USGS offices, indirect measurements from USGS reports, paeloflood events, peak-discharge events). The data collected from each of the four data sources are discussed in detail in the following sections of this report.

From the location, functions within ESRI ArcGIS 10 were used to populate additional data fields for each site (Environmental Systems Research Institute, Inc., 2011). The additional data fields are as follows:

1. County;

2. Eight-digit hydrologic unit code (HUC);

3. Basin-average 6-hour, 100-year precipitation, in inches, for the watershed upstream from flood site;

4. Mean watershed slope upstream from the flood site, in percent;

5. Mean annual precipitation, in inches, for the watershed upstream from the flood site;

6. Percent of watershed upstream from the flood site above 7,500 feet elevation (North American Vertical Datum of 1988);

7. Elevation of the flood site, in feet above the North American Vertical Datum of 1988. (Elevation is discussed later in the report.)

The elevation of the flood site refers to the approximate elevation of the actual flood site, not the water-surface elevation of a particular flood event. The ArcHydro Extension within ESRI ArcGIS 10 was used to generate watershed delineations for every site in the flood database (Maidment, 2002). Digital elevation models and derivative products for watershed delineation were obtained from the Colorado StreamStats database (U.S. Geological Survey, 2011b). Nine sites do not have watershed delineations, because they are canals, springs, or ditches; therefore, 
the contributing drainage area could not be determined by using the tools in ESRI ArcGIS 10 (Environmental Systems Research Institute, Inc., 2011).

Data for a number of fields for flood sites located at USGS streamgages (U.S. Geological Survey, 2011a) were obtained from the USGS NWIS database

(http://waterdata.usgs.gov/co/nwis/). The data fields include First year of peak-discharge record for each USGS streamgages, Last year of peak-discharge record for each USGS streamgage, Number of years of peak-discharge record for each USGS streamgage, and the USGS NWIS Web page for the streamgage. Flood sites not located at USGS streamgages were labeled "NA" (not applicable) in all of the previously mentioned data fields.

Table 1. Data fields composing the Colorado flood database for each flood site.

\begin{tabular}{|l|}
\hline \multicolumn{1}{|c|}{ Data field } \\
\hline Site identification number \\
\hline Site name \\
\hline U.S. Geological Survey station number \\
\hline Latitude (North American Datum of 1983) \\
\hline Longitude (North American Datum of 1983) \\
\hline County \\
\hline Drainage area, in square miles \\
\hline Eight-digit hydrologic unit code of flood site \\
\hline First year of peak-discharge record at U.S. Geological Survey streamgage \\
\hline Last year of peak-discharge record at U.S. Geological Survey streamgage \\
\hline Number of years of peak-discharge record at U.S. Geological Survey streamgage \\
\hline U.S. Geological Survey National Water Information System Web page of streamgage \\
\hline Basin-average 6-hour, 100-year precipitation, in inches, for the watershed upstream from flood site \\
\hline Mean watershed slope upstream from flood site, in percent \\
\hline Mean annual precipitation, in inches, of watershed upstream from flood site \\
\hline Percent of watershed upstream from flood site above 7,500-foot elevation (North American Vertical Datum of 1988) \\
\hline Elevation of flood site, in feet above the North American Vertical Datum of 1988 \\
\hline
\end{tabular}


Table 2. Data fields composing the Colorado flood database for each flood event, based on data source.

[NA, not applicable; ft3 s-1, cubic feet per second]

\begin{tabular}{|l|l|l|}
\hline \multicolumn{1}{|c|}{ Indirect discharge measurement ${ }^{1}$} & \multicolumn{1}{c|}{ Paleoflood events } & \multicolumn{1}{c|}{ Peak-discharge events } \\
\hline Site identification number & Site identification number & Site identification number \\
\hline Event identification number & Event identification number & Event identification number \\
\hline NA & $\begin{array}{l}\text { Largest flood in the last number of } \\
\text { years }\end{array}$ & NA \\
\hline NA & Reliability of the timeframe $( \pm$ years $)$ & NA \\
\hline Date of flood & NA & Date of flood \\
\hline Peak discharge of flood in $\mathrm{ft}^{3} \mathrm{~s}^{-1}$ & Peak discharge of flood in $\mathrm{ft}^{3} \mathrm{~s}^{-1}$ & Peak discharge of flood in $\mathrm{ft}^{3} \mathrm{~s}^{-1}$ \\
\hline NA & NA & Additional information about discharge \\
\hline NA & NA & Stage at peak discharge in feet \\
\hline NA & NA & Additional information about stage \\
\hline NA & NA & Largest discharge since year $\mathrm{X}$ \\
\hline $\begin{array}{l}\text { Field method used to determine peak } \\
\text { discharge }\end{array}$ & $\begin{array}{l}\text { Field method used to determine peak } \\
\text { discharge }\end{array}$ & $\begin{array}{l}\text { Field method used to determine peak } \\
\text { discharge }\end{array}$ \\
\hline Accuracy rating of peak discharge ${ }^{2}$ & Accuracy rating of peak discharge ${ }^{3}$ & NA \\
\hline Data source location & Data source location & Data source location \\
\hline Page number of data source & Page number of data source & NA \\
\hline Additional information & Additional information & NA \\
\hline
\end{tabular}

${ }^{1}$ This data field includes indirect measurement data stored in U.S. Geologcial Survey offices and data published in selected U.S Geological Survey reports.

${ }^{2}$ An indirect discharge measurement that was rated "good" has an uncertainty of \pm 10 percent, a "fair" rating has an uncertainty of \pm 15 percent, and a "poor" rating has an uncertainty of 25 percent or greater; however, the rating is subjective (Benson and Dalrymple, 1984).

${ }^{3}$ Accuracy rating (in percent) as report in the journal articles.

\section{Indirect Discharge Measurements Stored in U.S. Geological Survey Offices}

Data from indirect discharge measurements were compiled from files in USGS offices throughout the State of Colorado. Indirect discharge measurements determine the peak discharge of a flood event by using hydraulic equations and the water-surface profile and channel geometry, which is obtained by completing a field survey (Benson and Dalrymple, 1984). Every indirect discharge measurement found in paper files in the USGS offices was included in the flood database even if it was unpublished or incomplete. Flood-event data located in files that were labeled as unpublished or incomplete were included in the flood database, but the discharge for the flood event was listed as "unknown." A total of 906 flood events at 549 sites were compiled from indirect discharge measurements made during water years 1867 through 2011 and stored in USGS offices (fig. 1). 
In addition to the data fields populated using ESRI ArcGIS 10 tools and the USGS NWIS database, the following data fields were populated for indirect discharge measurements stored in USGS offices (tables 1 and 2): Site identification number, Site name, USGS station number, Latitude, Longitude, Drainage area, Event identification number, Date of flood, Peak discharge of flood, Field method used to determine peak discharge, Accuracy rating of peak discharge, Data source location, Page number of data source, and Additional information. The site and event identification numbers were unique arbitrary values assigned to every site and flood event without exception. The USGS station number was listed if the indirect discharge measurement was assigned to a particular USGS streamgage; otherwise, the site was listed as "miscellaneous." The latitude and longitude, in decimal degrees, and drainage area, in square miles, were determined using StreamStats, if the data were not already in the files (U.S. Geological Survey, $2011 b$ ). Three of the drainage areas could not be determined by using StreamStats because they drain to canals, springs, or ditches. As a result, if the drainage areas were not listed in the USGS NWIS database, the drainage areas were listed as "unknown" in the flood database. The site name listed in the USGS NWIS database was used in the flood database whenever possible. The exact day or month and day of the flood event was not known definitively for a very small number of events (18); therefore, the date of flood was listed with only the year or year and month, respectively. In the flood database, the date of flood was listed in year-month-day format (YYYY/MM/DD).

The peak discharge of the flood was reported in cubic feet per second, and if the peak discharge of the flood was unknown, it was listed as such in the flood database. Some indirect discharge measurements were made, not to determine the discharge of a particular flood event, but rather to better define or extend the stage-discharge rating at a particular site. These indirect discharge measurements were assigned a value of "NA" (not applicable) for the discharge because no actual flood occurred at that site, and the reason for the indirect discharge measurement was noted under the additional information data field. It was important to document the indirect discharge measurement whether or not it was for a specific flood event.

The field method used to determine the discharge was included in the flood database, or it was coded as "unknown." The 14 field methods that were used to compute indirect discharge measurements that are stored in USGS offices are listed in table 3 (Chow, 1959; Barnes and Davidian, 1978; Rantz and others, 1982; Benson and Dalrymple, 1984; England and others, 2003; Wilson and Richards, 2006). If the indirect discharge measurements were assigned an accuracy rating, the ratings were included in the flood database; alternatively, if there was no accuracy rating for the flood event, "unknown" was entered for the data field. An indirect discharge measurement that was rated "good" has an uncertainty of \pm 10 percent, a "fair" rating has an uncertainty of \pm 15 percent, and a "poor" rating has an uncertainty of 25 percent or greater; however, the rating is subjective (Benson and Dalrymple, 1984). Data source location reported the location where the data can be found for a particular flood event. The page number of data source was listed for indirect discharge measurements in order to keep the data fields consistent between the first data source (indirect discharge measurements stored in USGS offices) and the second (indirect discharge measurements in USGS reports) even though it was not applicable for any flood events from indirect discharge measurements stored in USGS offices. The additional information data field provides further detail about the flood event. The flood events that had no data for the additional information data field were coded as "NA." 


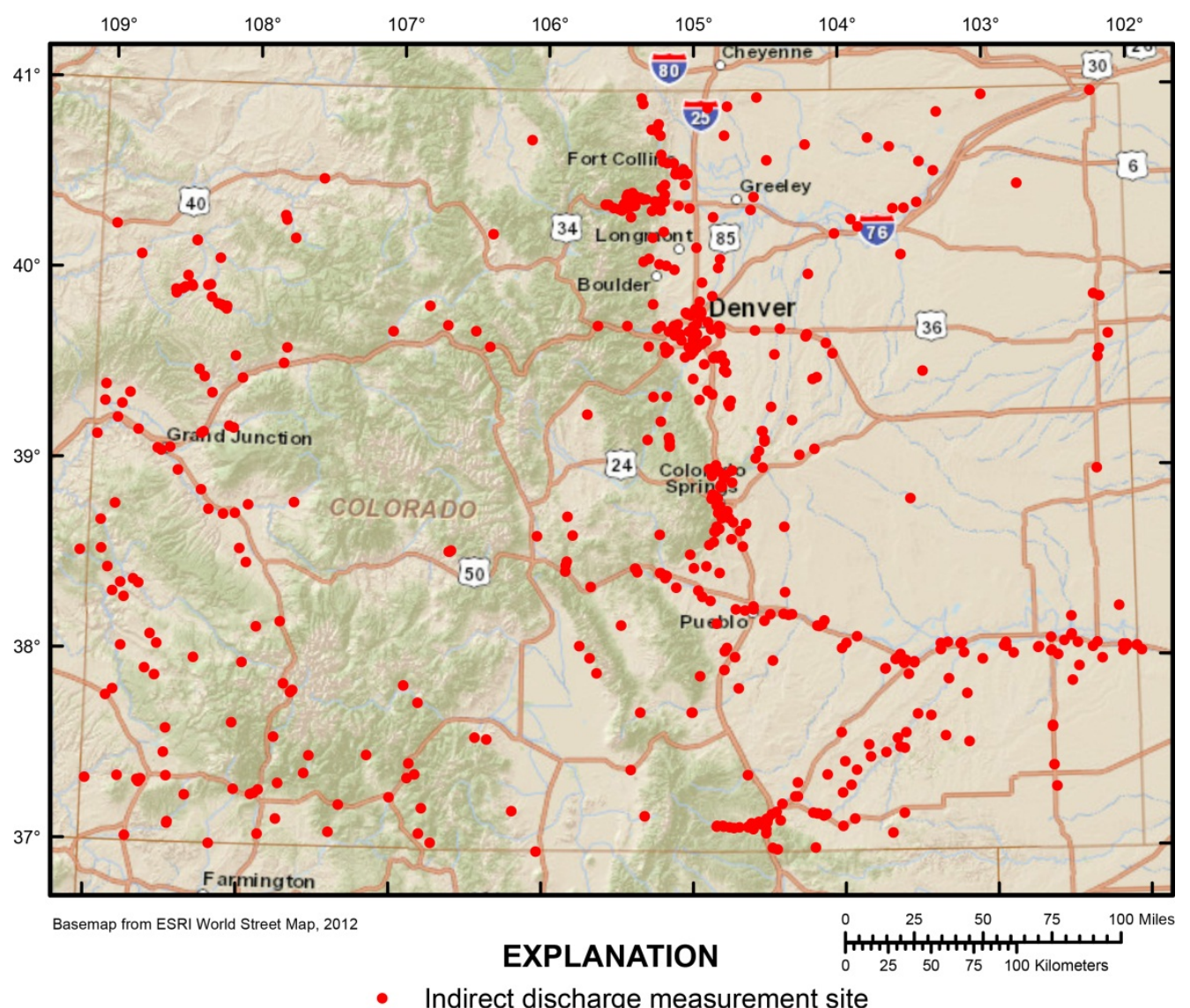

Figure 1. Location of 549 sites with indirect discharge measurements stored in U.S. Geological Survey offices in Colorado, water years 1867 through 2011. 
Table 3. The 14 field methods used to compute U.S. Geological Survey indirect discharge measurements for streams in Colorado.

\begin{tabular}{|c|l|}
\hline Number & \multicolumn{1}{|c|}{ Field method } \\
\hline 0 & Unknown \\
\hline 1 & Slope Area $^{1}$ \\
\hline 2 & Weir $^{2}$ \\
\hline 3 & Culvert $^{3}$ \\
\hline 4 & Contracted Opening $^{3}$ \\
\hline 5 & Float $^{2}$ \\
\hline 6 & Critical Depth $^{3}$ \\
\hline 7 & Step-Backwater $^{3}$ \\
\hline 8 & Flow Over Dam $^{3}$ \\
\hline 9 & Slope Conveyance $^{2}$ \\
\hline 10 & Area Capacity Computation $^{4}$ \\
\hline 11 & Velocity-Area $^{3}$ \\
\hline 12 & Kutter's Formula $^{5}$ \\
\hline 13 & Flow Competence $^{6}$ \\
\hline
\end{tabular}

${ }^{1}$ Benson and Dalrymple, 1984

${ }^{2}$ Rantz and others, 1982

${ }^{3}$ Barnes and Davidian, 1978

${ }^{4}$ Wilson and Richards, 2006

${ }^{5}$ Chow, 1959

${ }^{6}$ England and others, 2003

\section{Indirect Discharge Measurements in U.S. Geological Survey Reports}

Data on floods in Colorado from indirect discharge measurements were obtained from 73 USGS Water-Supply Papers, USGS Water-Data Reports, and USGS Open-File Reports. All known USGS reports that could have included information about indirect discharge measurements in Colorado were thoroughly searched. Every indirect discharge measurement found in the Colorado reports was included in the flood database whether it was made by the USGS, the Bureau of Reclamation, the Colorado Division of Water Resources, or any other agency. Only USGS reports were searched, but flood data from other agencies that were published in USGS reports were included in the flood database. A total of 200 flood events at 175 sites were compiled from indirect discharge measurements in USGS reports from water years 1884 through 2011 (fig. 2).

In addition to the data fields populated using ESRI ArcGIS 10 tools and the USGS NWIS database, the following data fields were populated for floods with indirect discharge measurements in USGS reports (tables 1 and 2): Site identification number, Site name, USGS station number, Latitude, Longitude, Drainage area, Event identification number, Date of flood, Peak discharge of flood, Field method used to determine peak discharge, Accuracy rating of peak discharge (good, fair, poor), Data source location, Page number of data source, and Additional 
information. All of the data fields for floods with indirect discharge measurements from USGS reports are the same as, and were treated the same as, the data fields in the previous section, indirect discharge measurements stored in USGS offices. However, the floods with indirect discharge measurements in USGS reports have the actual hyperlink to the report and the page number under the data source location and page number of the data source fields, respectively.

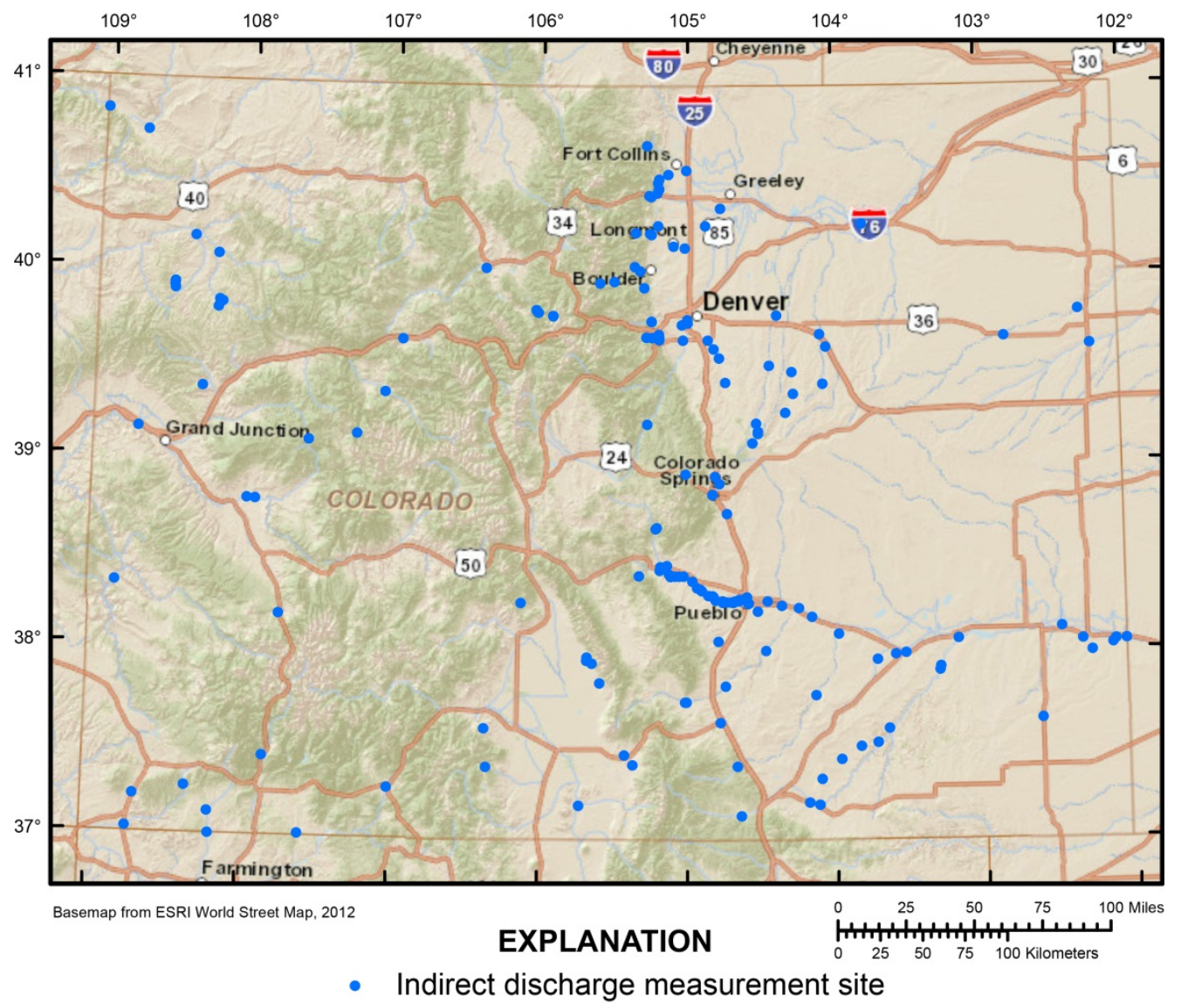

Figure 2. Location of the 175 flood sites in Colorado with indirect discharge measurements in U.S. Geological Survey reports, water years 1884 through 2011.

\section{Paleoflood Studies}

Data from six articles published in peer-reviewed journals (table 4) were compiled for 29 paleoflood studies at sites throughout Colorado located at USGS streamgages with records of events occurring in the past 5,000 to 10,000 years (fig. 3). Paleoflood studies use particle deposition from slack water, scars on trees, flood-transported sediment deposits, and erosional scars to determine the highest stage caused by floods prior to the study; the highest stage was in turn used to determine the paleoflood discharge (Jarrett and Tomlinson, 2000). Many other paleoflood studies were conducted at sites where there is no streamgage, and related articles were published in peer-reviewed journals. Information from those studies potentially could be added to the flood database. Determining the exact location of paleoflood studies conducted at 
sites without streamgages was beyond the scope of this study; therefore, data from those studies were not be included in the flood database.

All the data fields for the paleoflood studies are consistent with the data fields of the first two data sources with two exceptions - (1) Largest flood in the last number of years and (2) Reliability of the timeframe - which were added from the paleoflood journal articles. These two fields are not used for the indirect discharge measurement studies. Paleoflood studies record the time in which the flood occurred by using the largest flood in the last number of years instead of the traditional flood date. A reliability (plus or minus a certain number of years) is given to this timeframe in the journal article and was entered into the Reliability data field. In addition to the data fields determined by using tools in ESRI ArcGIS 10 and the USGS NWIS database, the following data fields were populated for the paleoflood studies (tables 1 and 2): Site identification number, Site name, USGS station number, Latitude, Longitude, Drainage area, Event identification number, Largest flood in the last number of years, Reliability of the timeframe, Peak discharge of flood, Field method used to determine peak discharge, Accuracy rating of peak discharge, Data source location, Page number of data source, and Additional information (tables 1 and 2). Instead of the good, fair, or poor accuracy rating used in the indirect discharge measurement studies, the accuracy rating assigned to the peak discharge was listed in percent as reported in the journal articles. 


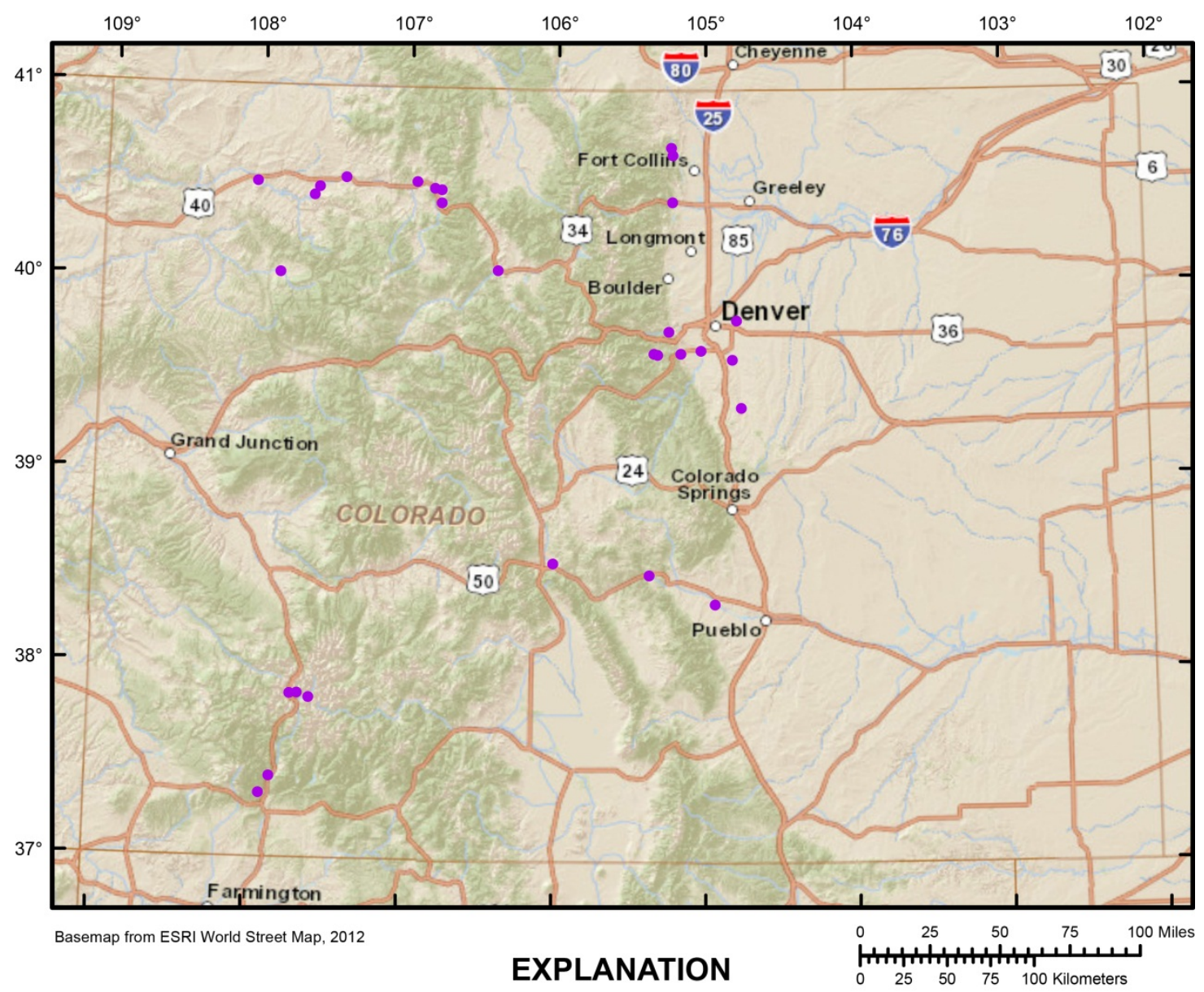

- Paleoflood study site

Figure 3. Location of the 29 paleoflood study sites in Colorado published in six peer-reviewed journal articles (England and others, 2003; England and others, 2010; Grimm and others, 1995; Jarrett, 2000; Jarrett and Tomlinson, 2000; Pruess and others, 1998). 
Table 4. Peer-reviewed journal articles related to floods in Colorado with the authors, journals, and dates of the paleoflood studies that were included in the Colorado flood database.

\begin{tabular}{|l|l|l|l|}
\hline \multicolumn{1}{|c|}{ Journal Article } & \multicolumn{1}{|c|}{ Author(s) } & \multicolumn{1}{|c|}{ Journal } & \multicolumn{1}{c|}{ Date } \\
\hline $\begin{array}{l}\text { Paleohydrologic bounds and extreme flood frequency of } \\
\text { the Upper Arkansas River, Colorado }\end{array}$ & $\begin{array}{l}\text { England, J.F. Jr., Godaire } \\
\text { J.E., Klinger, R.E., Bauer, } \\
\text { T.R., and Julian, P.Y. }\end{array}$ & Geomorphology & 2010 \\
\hline $\begin{array}{l}\text { Data-based comparisons of moments estimators using } \\
\text { historical and paleoflood data }\end{array}$ & $\begin{array}{l}\text { England, J.F. Jr., Jarrett, } \\
\text { R.D., and Salas, J.D. }\end{array}$ & Hydrology & 2003 \\
\hline $\begin{array}{l}\text { Coarse-Sediment Distribution as Evidence of an Elevation } \\
\text { Limit for Flash Flooding, Bear Creek, Colorado }\end{array}$ & $\begin{array}{l}\text { Grimm, M.M., Wohl, } \\
\text { E.E., and Jarrett, R.D. }\end{array}$ & Geomorphology & 1995 \\
\hline $\begin{array}{l}\text { Paleoflood investigations for Cherry Creek basin, Eastern } \\
\text { Colorado }\end{array}$ & Jarrett, R.D. & $\begin{array}{l}\text { American Society of } \\
\text { Civil Engineers } \\
\text { Conference } \\
\text { Proceeding }\end{array}$ & 2000 \\
\hline $\begin{array}{l}\text { Regional interdisciplinary paleoflood approach to assess } \\
\text { extreme flood potential }\end{array}$ & $\begin{array}{l}\text { Jarrett, R.D., and } \\
\text { Tomlinson, E.M. }\end{array}$ & $\begin{array}{l}\text { Water Resources } \\
\text { Research }\end{array}$ & 2000 \\
\hline $\begin{array}{l}\text { Methodology and implications of maximum } \\
\text { paleodischarge estimates for mountain channels, Upper } \\
\text { Animas River Basin, Colorado }\end{array}$ & $\begin{array}{l}\text { Pruess, J., Wohl, E.E., } \\
\text { and Jarrett, R.D. }\end{array}$ & $\begin{array}{l}\text { Artic and Alpine } \\
\text { Research }\end{array}$ & 1998 \\
\hline
\end{tabular}

\section{U.S. Geological Survey National Water Information System Peak-Discharge Database}

Data from every site in the USGS NWIS peak-discharge database in Colorado (http://waterdata.usgs.gov/co/nwis/), including active and inactive sites from water years 1883 through 2010, were compiled. Peak discharges in the USGS NWIS peak-discharge database were determined from the stage, which is recorded continuously at a streamgage. Using a stagedischarge relation, which is developed empirically by measuring the discharge several times at a various stages, the discharge can be determined for any stage (Rantz and others, 1982). To limit the results to the largest events that occurred at each site, only the five highest peaks per site were compiled in the flood database, which could include annual and secondary peaks.

The annual peak is the largest flood event that occurs in a given water year at a particular streamgage. A secondary peak is a flood event that is smaller than the annual peak but is still greater than the base discharge, and the trough between a secondary peak is 50 percent or less than an adjacent peak or the annual peak (Richard Crowfoot, U.S. Geological Survey, written commun., 2012). The base discharge is defined as the discharge which will be exceeded on average by at least three floods each year (Novak, 1985). If the site had fewer than five peaks recorded in the USGS NWIS peak-discharge database, those peaks were included in the flood database. For example, if one of the five highest peaks was characterized with low or no streamflow, it was included in the flood database as an indicator that the site is ephemeral. As a result, 5,631 flood events at 1,184 sites in the USGS NWIS peak-discharge database from water years 1883 through 2010 were included in the flood database (fig. 4). If flood-frequency 
analysis at a particular site is of interest, it is important to incorporate all the peaks of record from the USGS NWIS peak-discharge database.

The data fields for peak-discharge events that remained the same were treated in the same manner as described in the previous sections. The Accuracy rating of peak discharge and Additional information about the flood data fields used from the first three sources were omitted from the database. The following data fields were added: Additional information about discharge, Stage at peak discharge, Additional information about stage, and Largest discharge since year X. The stage is the water-surface elevation at the time of the flood event, typically relative to a local datum, recorded in feet. The local datum may be referenced to the North American Vertical Datum of 1929, the North American Vertical Datum of 1988, or an arbitrary datum. The USGS NWIS peak-discharge database is the only data source that provides information about the stream stage at the time of the flood event; stored in the Stage at peakdischarge data field.

In addition to the data fields determined by using ESRI ArcGIS 10 tools and the USGS NWIS database, the following data fields were obtained from the USGS NWIS peak-discharge database (tables 1 and 2): Site identification number, Site name, USGS station number, Latitude, Longitude, Drainage area, Event identification number, Date of flood, Peak discharge of flood, Additional information about discharge, Stage at peak discharge, Additional information about the stage, Largest discharge since year X, Field method used to determine peak discharge, and Data source location. Additional information about discharge and Additional information about the stage were recorded if data were available in the USGS NWIS peak-discharge database; otherwise, "NA" was reported in the data fields. The data fields for stage at peak discharge in feet and Largest discharge since year X were recorded if data were available in the USGS NWIS peak-discharge database; otherwise, "unknown" was recorded in the data fields. The exact day or month and day of the flood event was not known definitively for a small number of events (121); therefore, the date of flood was listed with only the year or year and month, respectively, for these special cases. 


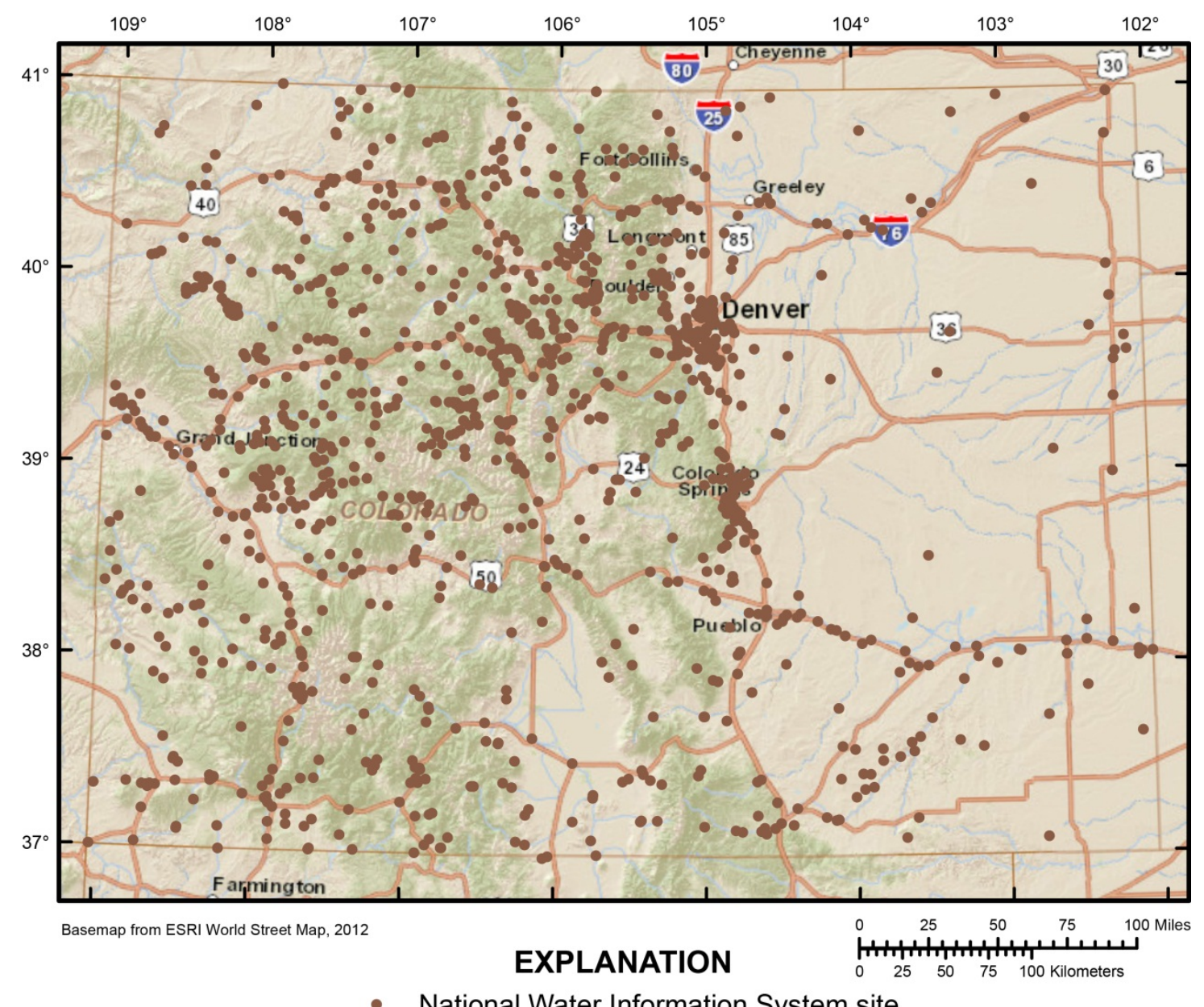

- National Water Information System site

Figure 4. Location of the 1,184 sites in the Colorado flood database obtained from the U.S. Geological Survey National Water Information System peak-discharge database, water years 1883 through 2010.

\section{Quality Assurance of the Data}

A number of tests were performed on the flood database to ensure the quality of the data. First, watershed delineations from the ESRI ArcHydro Extension within ESRI ArcGIS 10 could not be generated unless the coordinates of the site were in the USGS StreamStats stream network (U.S. Geological Survey, 2011b). Thus, if either the latitude or longitude were not accurate, the watershed delineation would not be generated. As a result, the latitude and longitude of several sites were adjusted slightly to correct them in order to generate the watershed delineation from ESRI ArcHydro Extension.

Second, the drainage area was computed within ESRI ArcGIS 10 and compared to the current drainage area, which was determined from the data source or by using StreamStats (Environmental Systems Research Institute, Inc., 2011; U.S. Geological Survey, 2011b). If the areas differed by more than 25 percent, the location of each site was examined individually to determine if there was an error in the location or drainage area. The erroneous data were then corrected. 
Third, every numerical data field in the flood database was sorted from smallest to largest. The extremes from each data field were then examined to determine if any of these values were outliers from the others in the data field. If the value seemed unreasonably high or low compared to the others or the values simply appeared to be unrealistic based on professional judgment, these flood events were re-evaluated, and the data were recomputed to determine the reason for the anomalies. The data were adjusted if any errors were uncovered.

Fourth, after the search options were built into the Web interface of the flood database, a number of the searchable data fields were used to determine if errors existed in those data fields. The data fields searched to check the quality of the data include the USGS station number, Site name, County, HUC, Drainage area, and Elevation of flood site. The USGS station numbers were searched to ensure that a station was not located in more than one location in Colorado. The site names were searched to ensure that all rivers or streams with similar names were in fact on the same stream. The county and HUC data fields were searched to ensure that every site fell within the correct region. The drainage area and elevation were searched to ensure that each increased and decreased, respectively, as the distance from the Continental Divide increased (not shown on a map in this report).

\section{Web Interface}

The Web interface was programmed using the ESRI ArcGIS JavaScript API 3.2 and can be accessed at http://cwscpublic2.cr.usgs.gov/projects/coflood/COFloodMap.html. The sites of the flood events were compiled into a geodatabase using ESRI ArcGIS 10 (Environmental Systems Research Institute, Inc., 2011). This geodatabase of flood events was depicted in a map document using ESRI ArcGIS 10 and converted to a map service with ESRI ArcGIS Server 10 (Environmental Systems Research Institute, Inc., 2012a). The ESRI ArcGIS JavaScript API 3.2 provides tools to display map services through embedded map-based applications within the Web pages (Environmental Systems Research Institute, Inc., 2012b). ESRI ArcGIS JavaScript API 3.2 allows for the display, query, georeference, and export of the data in the flood database. The map interface has a number of interchangeable background maps, including a street map, aerial map, topographic map, and terrain map, along with the county and HUC boundaries and the Colorado Department of Transportation milepost and bridge layers. The search and filter options (appendix 1) are located to the left of the on-screen map in the search and filter toolbars with the results appearing below the map (fig. 5). Data points appear on the Web map that correspond to each unique site where a flood event or several flood events occurred. 


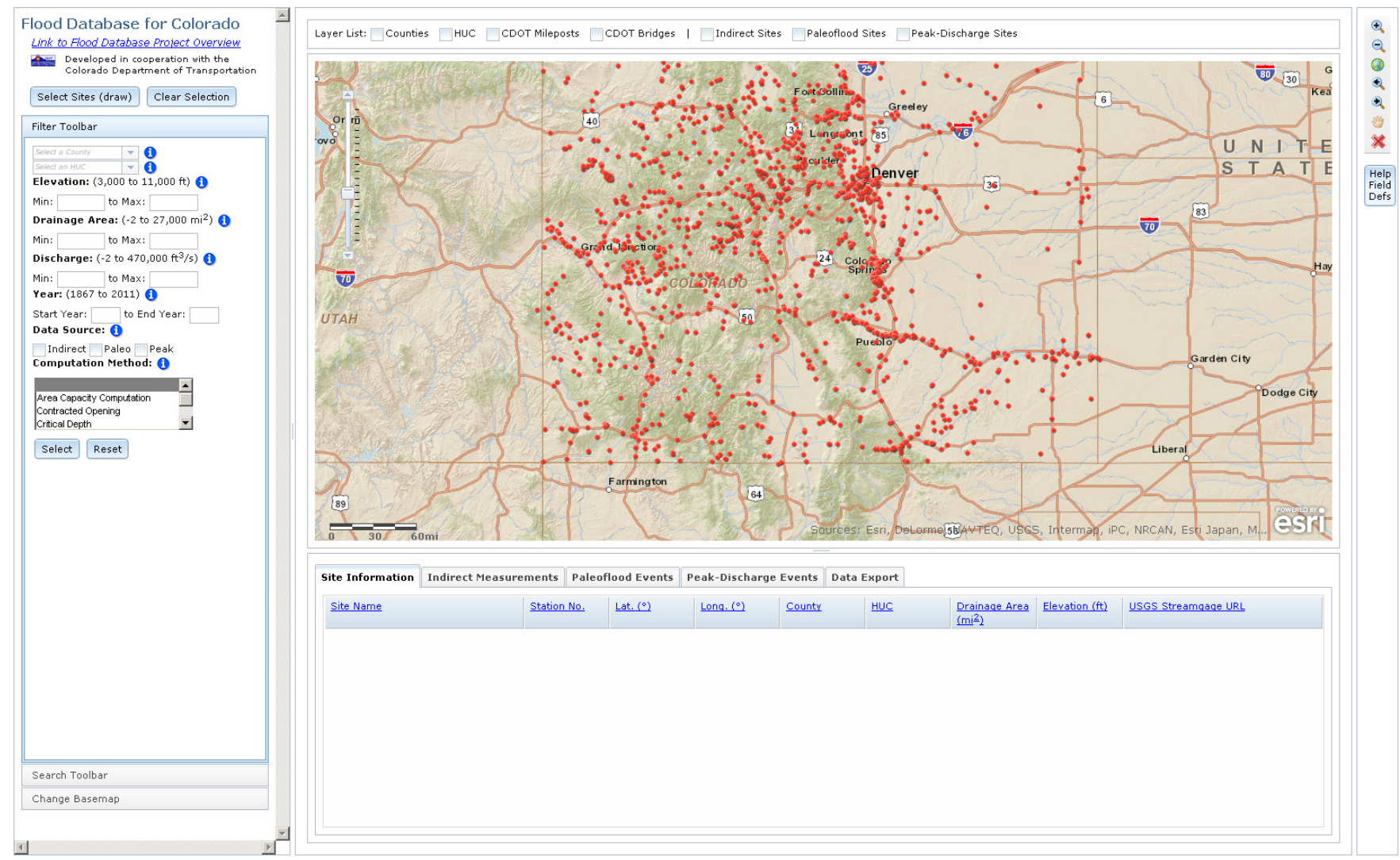

Figure 5. Screen capture of the home page of the flood database with all 1,597 flood sites in Colorado.

\section{Database Structure}

To display the flood database on the Web and allow the flood database to be easily queried, the database is organized into two types of tables that are outlined in tables 1 and 2 of this report. Table 1 includes all the site-specific data fields, and table 2 includes all the data fields that are unique to a particular flood event. Table 2 is spilt into three columns on the basis of the data source: the indirect discharge measurements column, which includes indirect discharge measurements originally stored in USGS offices and flood data from indirect discharge measurements in USGS reports; the paleoflood events column, which pertains to the paleoflood studies from six journal articles (table 4); and the NWIS peak-discharge events column, which pertains to the USGS NWIS peak-discharge events. Two data sources (indirect discharge measurements stored in the USGS offices and flood data from indirect discharge measurements in USGS reports) were combined into a single column, the Indirect discharge measurement column, because they had exactly the same data fields. The last two data sources have unique data fields so these were given individual columns.

Every event in the flood event table (table 2) is linked to only one flood site. Every site in the site table (table 1) is linked to at least one but potentially many events. Sites that were less than 1,000 feet from each other and were without tributary inflow were combined into a single site for simplicity. Some USGS streamgages may be identified with more than one site, as some indirect discharge measurements were performed near the streamgage but not necessarily within 
1,000 feet of the streamgage, and some streamgages may have been moved slightly over the course of time. (Changes in the location of a streamgage are recorded in the NWIS station information.) Wherever possible, the exact location of the flood event was preserved and included in the database even though that may result in more than one flood site per USGS streamgage.

\section{Database Tools and Features}

A number of tools and features were designed so that the user can search the flood database and retrieve and export data in a usable format. The assorted background maps and layers provide spatial reference. The variety of search options, discussed in detail in the next section, allows users to narrow the results. The output options available to the user also are discussed below.

\section{Search Options}

The user can search the flood database from the Web interface by using two options. Option one - selecting flood data from the database using the interface. The user selects an individual data point on the map or draws a box over an entire region in Colorado to select every data point in the box.

Option two-filtering data. This option offers not only a search component, but also a way to filter results from the first search option. Option two is the search and filter toolbars (fig. 6). The user can search the entire flood database by using any number of data fields to filter the results. Additionally, the search results from previous search options can be filtered by using a number of data fields. The data fields in the flood database that can be used to search or filter the database include HUC, USGS station number, Site name, County, Drainage area, Elevation, Data source (indirect measurement data stored in USGS offices, indirect discharge measurements from USGS report, paleoflood events, peak-discharge events), Date of flood, Peak-discharge, and Field method used to determine discharge. There are additional data fields in the database that can be viewed and exported, but the previously listed data fields are the only ones that can be used for queries. An example of a search of the Colorado flood database for flood data in Jefferson County for a specified elevation, drainage area, and discharge is shown in appendix 1. 


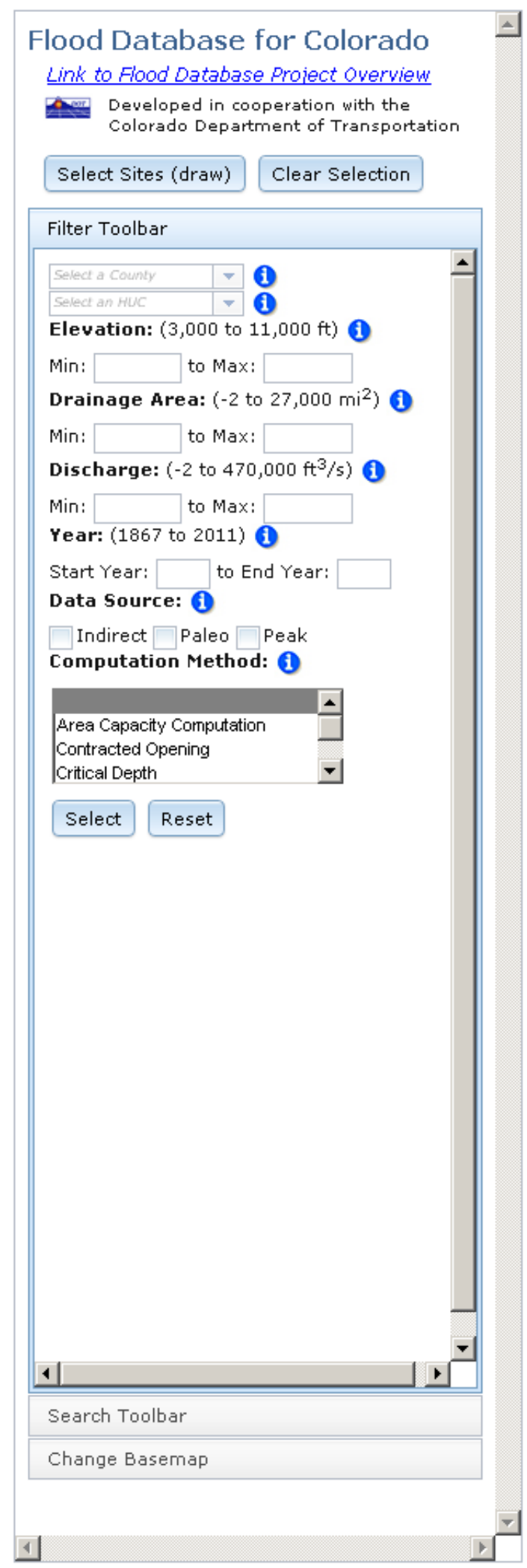

A. Search tool bar

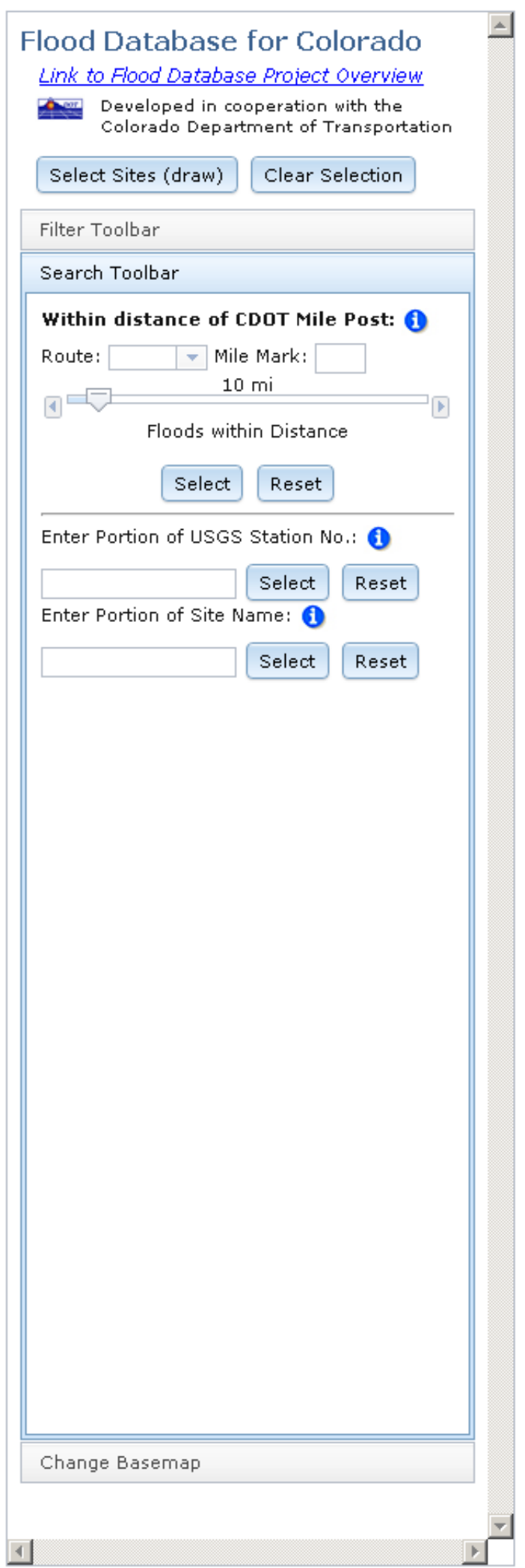

B. Filter tool bar

Figure 6. Screen capture of the search and filter toolbars of the Colorado flood database. 


\section{Output Options}

After the user has completed the search and filtered the results. A list of sites and flood events will appear in the four tables below the map when tabs (site information, indirect measurements, paleoflood events, and peak-discharge events, data export) are activated. Each table displays selected data fields for simplicity; yet enough fields are displayed to keep the sites and events separate. After selecting an individual flood event from this list, an ASCII file with all the data fields pertaining to that flood event is produced by using the data export tab (fig. 7). The user also may select several or all of the floods from the results list; the flood database will return all the data fields in a table that can be exported in ASCII format. The watershed delineation for all of the flood sites in the database is available for export as well, with the exception of some (10) sites that are canals, springs, or ditches.

\begin{tabular}{|l|l|l|l|l|}
\hline Site Information & Indirect Measurements & Paleoflood Events & Peak-Discharge Events & Data Export \\
\hline
\end{tabular} 
data on 906 flood events at 549 sites compiled from indirect discharge measurements stored in USGS offices from water years 1867 through 2011. A total of 200 flood events at 175 sites were compiled in the flood database from indirect discharge measurements in USGS reports from water years 1884 through 2011. Data from six paleoflood studies conducted at USGS streamgages from water years 1995 to 2010 and published in peer-reviewed journal articles were compiled in the flood database to generate a total of 29 paleoflood sites throughout Colorado with data on events occurring in the past 5,000 to 10,000 years. The Web-based flood database includes 5,631 flood events at 1,184 sites from water years 1883 through 2010 compiled from the USGS NWIS peak-discharge database.

The database can be accessed at http://cwscpublic2.cr.usgs.gov/projects/coflood/COFloodMap.html. The Web interface was programmed using the ESRI ArcGIS JavaScript API 3.2. ESRI ArcGIS JavaScript API 3.2 allows for the display, query, georeference, and export of the data in the flood database. The data fields in the flood database used to search and filter the database include hydrologic unit code, U.S. Geological Survey station number, site name, county, drainage area, elevation, data source (indirect discharge measurements stored in USGS offices or in USGS reports, the USGS National Water Information System peak-discharge database, and paleoflood events), date of flood, peak discharge, and field method used to determine discharge. Additional flood data on documented floods in Colorado are available from non-USGS sources (other Federal, State, and local government agencies, consultants, and universities), and though it was beyond the scope of this study to locate that data, the data could be compiled and incorporated in this flood database.

\section{References Cited}

Barnes, H.H., Jr., and Davidian, J., 1978, Indirect methods in hydrometry, in Herschy, R.W., ed. Hydrometry: New York, John Wiley and Sons, p. 149-204.

Benson, M.A., and Dalrymple, T., 1967, General field and office procedures for indirect discharge measurements (4th ed., revised) [editorial corrections made 1984]: U.S. Geological Survey Techniques of Water-Resources Investigations, book 3, chap. A1, p. 30.

Chow, V.T., 1959, Open-channel hydraulics: New York, McGraw-Hill, p. 680.

England, J.F. Jr., Godaire J.E., Klinger, R.E., Bauer, T.R., and Julian, P.Y., 2010, Paleohydrologic bounds and extreme flood frequency of the Upper Arkansas River, Colorado: Geomorphology, v. 124, p. 1-16.

England, J.F. Jr., Jarrett, R.D., Salas, J.D., 2003, Data-based comparisons of moments estimators using historical and paleoflood data: Journal of Hydrology, v. 278, p. 172-196.

Environmental Systems Research Institute, Inc., 2011, ArcGIS-A complete integrated system: Redlands, Calif., Environmental Systems Research Institute, Inc., accessed April 2011 at http://www.esri.com/software/arcgis/.

Environmental Systems Research Institute, Inc., 2012a, ArcGIS for Server: Redlands, Calif., Environmental Systems Research Institute, Inc., accessed June 2012 at http://www.esri.com/software/arcgis/arcgisserver/index.html/.

Environmental Systems Research Institute, Inc., 2012b, ArcGIS API for JavaScript: Redlands, Calif., Environmental Systems Research Institute, Inc., accessed June 2012 at http://help.arcgis.com/en/webapi/javascript/arcgis/index.html. 
Grimm, M.M., Wohl, E.E., and Jarrett, R.D., 1995, Coarse-sediment distribution as evidence of an elevation limit for flash flooding, Bear Creek, Colorado: Geomorphology, v. 14, no. 12, p. 199-210.

Interagency Committee on Water Data, 1982, Guidelines for determining flood flow frequency: Washington D.C., Hydrology Subcommittee, Bulletin 17-B, 28 p. (revised and corrected).

Jarrett, R.D., 2000, Paleoflood investigations for Cherry Creek basin, Eastern Colorado: 2000 Joint Conference on Water Resources Engineering and Water Resources Planning and Management [Proceedings], Minneapolis, Minn., July 30 - August 2, 2000, Reston, Va.: American Society of Civil Engineers, p. 1-10.

Jarrett, R.D., and Tomlinson, E.M., 2000, Regional interdisciplinary paleoflood approach to assess extreme flood potential, Water Resources Research., v. 36, no. 10, p. 2957-2984.

Maidment, D.R., 2002, Arc Hydro: GIS for water resources: Redlands, Calif., Environmental Systems Research Institute, Inc. 220 p.

Novak, C.E., 1985, Water Resources Division data reports preparation guide: U.S. Geological Survey Open-File Report 85-480, p. 92-93.

Pruess, J., Wohl, E.E., and Jarrett, R.D., 1998, Methodology and implications of maximum paleodischarge estimates for mountain channels, Upper Animas River Basin, Colorado: Artic and Alpine Research, v. 30, no. 1, p. 40-50.

Rantz, S.E., and others, 1982, Measurement and computation of streamflow, volume 2, Computation of discharge: U.S. Geological Survey Water Supply Paper 2175, p. 389.

U.S. Geological Survey, 2011a, National Water Information System, accessed January 2011 at http://waterdata.usgs.gov/co/nwis/.

U.S. Geological Survey, 2011b, Colorado StreamStats, accessed January 2011 at http://streamstatsags.cr.usgs.gov/co_ss/default.aspx? stabbr $=$ co\&dt $=1323879434710$.

Wilson, G.L., and Richards, J.M., 2006, Procedural documentation and accuracy assessment of bathymetric maps and area/capacity tables for small reservoirs: U.S. Geological Survey Scientific Investigations Report 2006-5208, 24 p. 


\section{Appendix 1. Example of a Data Search and Retrieval Using the Colorado Web-Based Flood Database}

\section{Procedures for searching and retrieving data using the Search and Filter Toolbar of the Colorado Web-based flood database}

1. Navigate to the flood database at http://cwscpublic2.cr.usgs.gov/projects/coflood/COFloodMap.html.

2. In the search and filter toolbar on the left side of the window shown in figure 1-1, select the following:
a. "Jefferson" as the county,
b. " 5,500 " feet as the minimum elevation and " 6,000 " feet as the maximum elevation,
c. " 50 " square miles as the minimum drainage area, and
d. "2,500" cubic feet per second as the minimum discharge.

3. View the results at the bottom of the window and results in tabs, which are based on the site and source of data.
a. Figure 1-2 displays the results in the site information tab.
b. Figure 1-3 displays the results in the indirect measurements tab.
c. Figure 1-4 displays the results in the paleoflood events tab.
d. Figure 1-5 displays the results in the peak-discharge events tab.
e. Figure 1-6 displays the results in the data export tab and the resulting ASCII file with all the data fields for each event.




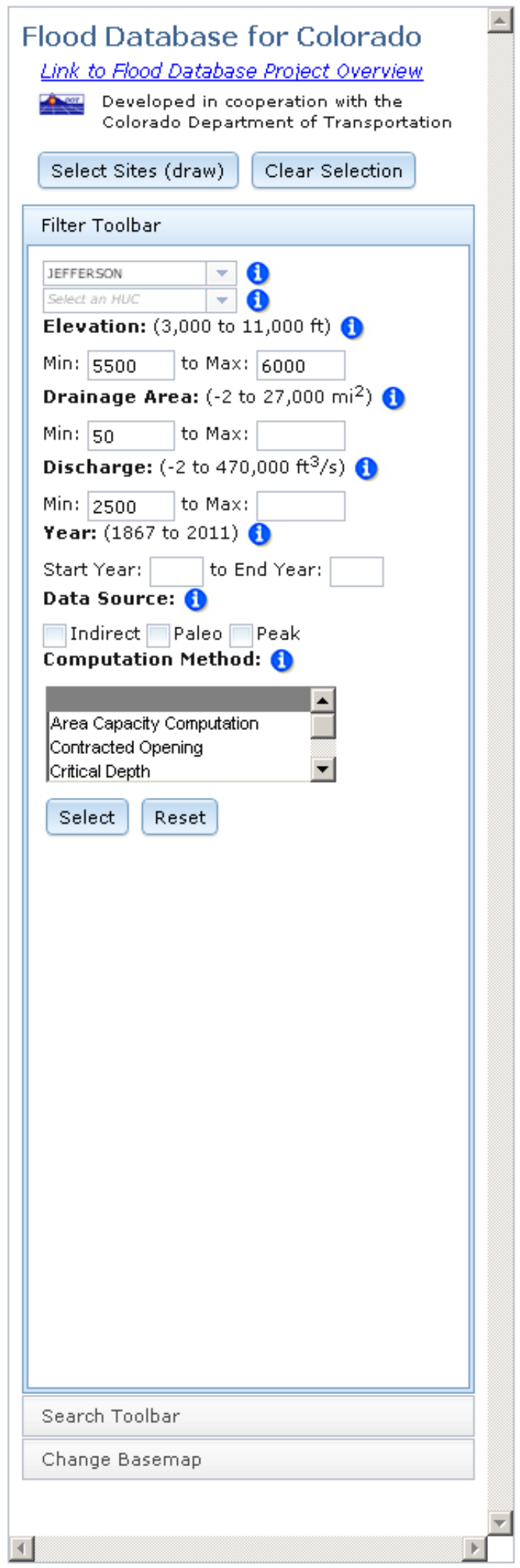

Figure 1-1. Screen capture of the search and filter options for the example search for floods in Jefferson County in the Colorado flood database. 


\begin{tabular}{|c|c|c|c|c|c|c|c|c|}
\hline \multirow{2}{*}{$\begin{array}{l}\text { Site Information (4) } \\
\text { Site Name }\end{array}$} & Indirect Measurements (8) & \multicolumn{2}{|c|}{ Paleoflood Events (2) P } & \multicolumn{2}{|c|}{ Peak-Discharge Events (11) } & Data Export (21) & \multirow[b]{2}{*}{ Elevation (ft) } & \multirow[b]{2}{*}{ USGS Streamqage URL } \\
\hline & Station No. & Lat. $\left({ }^{\circ}\right)$ & Long. $\left({ }^{\circ}\right)$ & County & HUC & $\frac{\text { Drainaqe Area }}{\left(m \mathrm{~m}^{2}\right)}$ & & \\
\hline BEAR CREEK AT MORRISON, CO. & 06710500 & 39.653056 & -105.195000 & JEFFERSON & 10190002 & 164 & 5,780 & $\begin{array}{l}\text { http://waterdata.usqs.q0v/co/nwis/in } \\
\text { ventory/?site no }=06710500\end{array}$ \\
\hline $\begin{array}{l}\text { TURKEY CREEK NEAR MORRISON, } \\
\text { COLORADO }\end{array}$ & 06711000 & 39.635556 & -105.168056 & JEFFERSON & 10190002 & 50.1 & 5,740 & $\begin{array}{l}\text { http:///waterdata.usqs.q0V/co/nwis/in } \\
\text { ventory/?site no }=06711000\end{array}$ \\
\hline BEAR CREEK AT MORRISON, CO & 06710500 & 39.652800 & -105.195400 & JEFFERSON & 10190002 & 164 & 5,780 & $\begin{array}{l}\text { http://waterdata.usqs. } 0 \text { ov/co/nwis/in } \\
\text { ventorv/?site no }=06710500\end{array}$ \\
\hline CLEAR CREEK NEAR GOLDEN, $C O$. & 06719500 & 39.750543 & -105.248878 & JEFFERSON & 10190004 & 399 & 5,740 & $\begin{array}{l}\text { http://waterdata.usqs.qov/co/nwis/in } \\
\text { ventor/?/site no=06719500 }\end{array}$ \\
\hline
\end{tabular}

Figure 1-2. Screen capture of the site information tab with results for the example search in the Colorado flood database.

\begin{tabular}{|l|l|l|l||l|}
\hline Site Information (4) & Indirect Measurements (8) & Paleoflood Events (2) & Peak-Discharge Events (11) & Data Export (21) \\
\hline
\end{tabular}

\begin{tabular}{|c|c|c|c|}
\hline Site Name & Date $(M / M / M M / D D)$ & Discharge $\left(\mathrm{ft}^{3}-\mathrm{s}\right)$ & Data Source Location \\
\hline BEAR CREEK AT MORRISON, CO. & $1896 / 07 / 24$ & 8,600 & http://pubs.usqs.qov/wsp/0997/report.pdf \#page $=150$ \\
\hline BEAR CREEK AT MORRISON, CO. & $1907 / 08 / 27$ & 4,000 & http://pubs.usqs.q0v/wsp/0246/report.pdf \#paqe $=308$ \\
\hline BEAR CREEK AT MORRISON, $\mathrm{CO}$. & $1941 / 06 / 21$ & 2,500 & http://pubs.usqs.q0v/wsp/0926/report.pdf \#page $=348$ \\
\hline BEAR CREEK AT MORRISON, CO. & $1933 / 07 / 07$ & 8,110 & Lakewood Main Office \\
\hline BEAR CREEK AT MORRISON, CO. & $1938 / 09 / 02$ & 6,200 & Lakewood Main Office \\
\hline CLEAR CREEK NEAR GOLDEN, CO. & $1938 / 09 / 02$ & 4,090 & http://pubs.usqs.q0v/wsp/0856/report.pdf \#paqe $=291$ \\
\hline CLEAR CREEK NEAR GOLDEN, CO. & $1941 / 06 / 22$ & 5,140 & http://pubs.usqs.q0v/wsp/0926/report.pdf \#paqe $=352$ \\
\hline CLEAR CREEK NEAR GOLDEN, CO. & $1933 / 09 / 09$ & 5,890 & Lakewood Main Office \\
\hline
\end{tabular}

Figure 1-3. Screen capture of the indirect measurements tab with results for the example search in the Colorado flood database. 


\begin{tabular}{|c|c|c|c|c|c|}
\hline Site Information (4) & Indirect Measurements (8) & Paleoflood Events ( & (2) Peak-Discharge Events (11) & Data Export (21) & \\
\hline \multicolumn{2}{|l|}{ Site Name } & $\begin{array}{l}\text { Largest Flood in the Last (This Many) } \\
\text { Years }\end{array}$ & Reliability (Years) & Discharge $\left(\mathrm{ft}^{3} / \mathrm{s}\right)$ & Data Source Location \\
\hline $\begin{array}{l}\text { TURKEY CREEK NEAR MORRISON, } \\
\text { COLORADO }\end{array}$ & \multicolumn{2}{|l|}{2556} & \pm 53 & 2,610 & 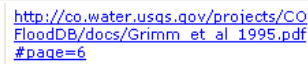 \\
\hline CLEAR CREEK NEAR GC & OLDEN, CO. & & UNKNOWN & 50,100 & $\begin{array}{l}\frac{\text { http://co. water.usqs.qov/proiects/Co }}{\text { FloodDB/docs/enaland and others 2 }} \\
0.03 . \text { dff \#page }=8\end{array}$ \\
\hline
\end{tabular}

Figure 1-4. Screen capture of the paleoflood events tab with results for the example search in the Colorado flood database.

\begin{tabular}{|c|c|c|c|c|}
\hline Site Information (4) & Indirect Measurements (8) & Paleoflood Events (2) Pe & Peak-Discharge Events (11) & Data Export (21) \\
\hline \multicolumn{2}{|l|}{ Site Name } & Date $(M / M / M M / D D)$ & Discharqe $\left(\mathrm{ft}^{3} / \mathrm{s}\right)$ & Data Source Location \\
\hline \multicolumn{2}{|c|}{ TURKEY CREEK NEAR MORRISON, COLORADO } & $1969 / 05 / 07$ & 2,730 & $\begin{array}{l}\text { http://nwis. waterdata.usqs.qov/co/nwis/peak? } \\
\text { site no=06711000 }\end{array}$ \\
\hline \multicolumn{2}{|c|}{ BEAR CREEK AT MORRISON, CO } & $1896 / 07 / 24$ & 8,600 & $\begin{array}{l}\text { http://nwis. waterdata.usqs.q0v/co/nwis/peak? } \\
\text { site no }=06710500\end{array}$ \\
\hline \multicolumn{2}{|c|}{ BEAR CREEK AT MORRISON, CO } & $1933 / 07 / 07$ & 8,110 & $\begin{array}{l}\text { http: //nwis. waterdata.usqs.q0V/co/nwis/peak? } \\
\text { site no }=06710500\end{array}$ \\
\hline \multicolumn{2}{|c|}{ BEAR CREEK AT MORRISON, CO } & $1934 / 08 / 09$ & 4,620 & $\begin{array}{l}\text { http://nwis, waterdata.usqs. qov/co/nwis/peak? } \\
\text { site no }=06710500\end{array}$ \\
\hline \multicolumn{2}{|c|}{ BEAR CREEK AT MORRISON, CO } & $1938 / 09 / 02$ & 6,200 & $\begin{array}{l}\text { http://nwis. waterdata.usqs. qov/co/nwis/peak? } \\
\text { site no }=06710500\end{array}$ \\
\hline \multicolumn{2}{|c|}{ BEAR CREEK AT MORRISON, CO } & $1983 / 07 / 22$ & 4,140 & $\begin{array}{l}\text { http://nwis, waterdata.usqs.qov/co/nwis/peak? } \\
\text { site no=06710500 }\end{array}$ \\
\hline \multicolumn{2}{|c|}{ CLEAR CREEK NEAR GOLDEN, CO. } & $1921 / 07 / 31$ & 4,420 & $\begin{array}{l}\text { http://nwis. waterdata. usqs. qov/co/nwis/peak? } \\
\text { site no=06719500 }\end{array}$ \\
\hline \multicolumn{2}{|c|}{ CLEAR CREEK NEAR GOLDEN, $\mathrm{CO}$. } & $1933 / 09 / 09$ & 5,890 & $\begin{array}{l}\text { http://nwis. Waterdata.usqs. qov/co/nwis/peak? } \\
\text { site no=06719500 }\end{array}$ \\
\hline \multicolumn{2}{|c|}{ CLEAR CREEK NEAR GOLDEN, CO. } & $1935 / 08 / 03$ & 4,900 & $\begin{array}{l}\text { http: //nwis, waterdata. usqs. qov/co/nwis/peak? } \\
\text { site no }=06719500\end{array}$ \\
\hline \multicolumn{2}{|c|}{ CLEAR CREEK NEAR GOLDEN, CO. } & $1941 / 06 / 22$ & 5,140 & $\begin{array}{l}\text { http://nwis, waterdata.usqs. qov/co/nwis/peak? } \\
\text { site no }=06719500\end{array}$ \\
\hline \multicolumn{2}{|c|}{ CLEAR CREEK NEAR GOLDEN, CO. } & $1956 / 06 / 04$ & 5,250 & $\begin{array}{l}\text { http://nwis. waterdata. Usqs. qov/co/nwis/peak? } \\
\text { site no }=06719500\end{array}$ \\
\hline
\end{tabular}

Figure 1-5. Screen capture of the peak-discharge events tab with results for the example search in the Colorado flood database. 


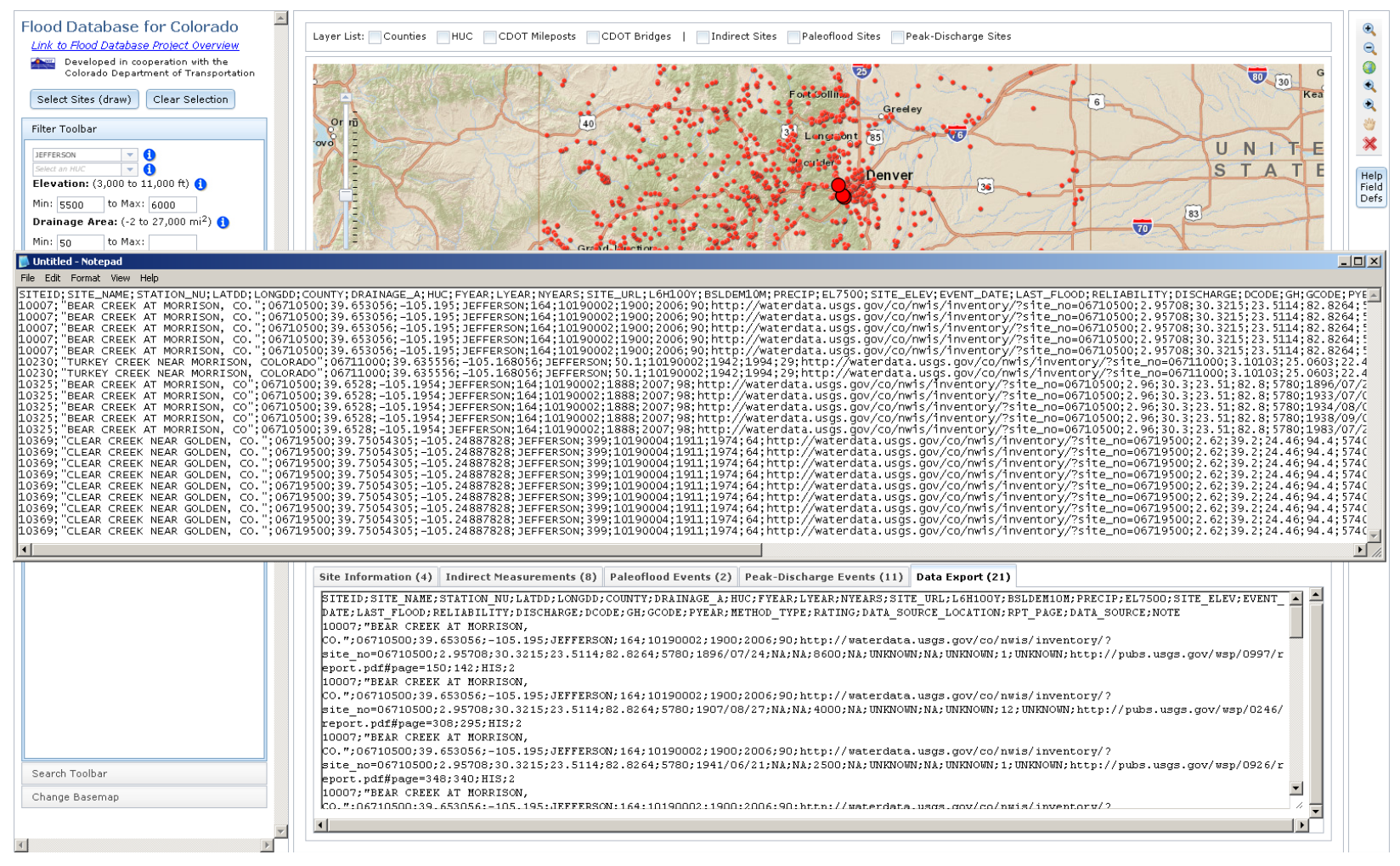

Figure 1-6. Screen capture of the data export tab with results in an ASCII file for all the data fields for each event in the example search in the Colorado flood database. 